\title{
OPTIMASI FORMULA NANOEMULSI GEL EKSTRAK BUAH BAKAU HITAM (Rhizophora mucronataLamk.) DENGAN VARIASI GELLING AGENT HPMC, CARBOPOL 940 DAN VISCOLAM MAC 10
}

\author{
Meliana Inda Setiawati $^{* 1}$, Elisa Issusilaningtyas ${ }^{2}$, Lulu Setiyabudi $^{3}$ \\ ${ }^{1,2,3}$ STIKES Al-Irsyad Al-Islamiyyah, Cilacap, Jawa Tengah, Indonesia \\ e-mail: ${ }^{* 1}$ melianaindasetiawati459@gmail.com, ${ }^{2}$ elisa12211@gmail.com, ${ }^{3}$ l.setiyabudi@gmail.com
}

\begin{abstract}
ABSTRAK
Buah bakau hitam (Rhizophora mucronata Lamk.) mempunyai aktivitas antioksidan dengan komponen aktifnya adalah alkaloid, flavonoid, steroid, fenol hidroquinon, dan tanin. Dalam penelitian ini dipilih sediaan nanoemulgel sebagai kosmetik untuk antioksidan. Tujuan dari penelitian ini yaitu untuk mengetahui komposisi optimum campuran gelling agent untuk menghasilkan nanoemulgel ekstrak buah bakau hitam yang memenuhi sifat fisik dan stabilitas yang baik. Optimasi menggunakan metode Simplex Lattice Design (SLD) dengan variasi gelling agent menggunakan HPMC, Carbopol 940 dan Viscolam MAC 10 yang diperoleh sebanyak empat belas formula, dengan karakteristik fisik organoleptis, pH, homogenitas, daya sebar, viskositas dan stabilitas fisik perubahan viskositas dengan metode freeze thaw. Data dinalisis menggunakan simplex design expert 10.0.1 dan uji t serta deskriptif. Hasil formulasi optimum campuran gelling agent untuk menghasilkan nanoemulgel ekstrak buah bakau hitam yang memenuhi sifat fisik dan stabilitas yang baik adalah nanoemulgel pada formula VI, dan pada hasil penentuan formula optimum nanoemulgel ekstrak buah bakau hitam diperoleh dengan campuran HPMC 0,024\%, carbopol 940 0,38\% dan viscolam MAC 10 0,59\%. Dengan nilai respon yang diperoleh untuk evaluasi dengan daya sebar 2,21 cm, viskositas 49043,2 Cps dan perubahan viskositas 579,3 Cps.
\end{abstract}

Kata kunci: Antioksidan, Buah Bakau Hitam (Rhizophora mucronata Lamk.), Nanoemulgel, Optimasi Simplex Lattice Design (SLD), Variasi gelling agent.

\begin{abstract}
Black mangrove fruit (Rhizophora mucronata Lamk.) has antioxidant activity with active components are alkaloids, flavonoids, steroids, phenol hydroquinone and tannins. In this study nanoemulgel preparations were chosen as cosmetics for antioxidants. The purpose of this study was to determine the optimum composition of a mixture of gelling agent to produce black mangrove extract nanoemulgel that fulfills good physical properties and stability. Optimization using the Simplex Lattice Design (SLD) method with a variety of gelling agent using HPMC, carbopol 940 and viscolam MAC 10 obtained as many as fourteen formulas, with organoleptic physical characteristics, $\mathrm{pH}$, homogeneity, dispersibility, viscosity and physical stability of viscosity changes with the freeze thaw method were analyzed using Simplex Design Expert 10.0.1 and $t$-test as well as descriptive. The optimum formulation of the gelling agent mixture to produce black mangrove extract nanoemulgel that fulfills good physical properties and stability is nanoemulgel in formula VI, and the results of determining the optimal nanoemulgel formula for black mangrove extract were obtained with a mixture of HPMC 0,024\%, carbopol 940 0,38\% and viscolam MAC 10 0,59\%. With the response value obtained for the evaluaation with the spread power of 2,21 cm, viscosity 49043,2 Cps and change in viscosity 579,3 Cps.
\end{abstract}

Keywords: Antioxidants, Black Mangrove Fruit (Rhizophora mucronat Lamk.), Nanoemulgel, Simplex Lattice Design (SLD) Optimization, Gelling agent variations.

\section{PENDAHULUAN}

Kepulauan Indonesia memiliki luas hutan mangrove terbesar di Asia [1]. Diperkirakan luas hutan mangrove yang ada di Indonesia sekitar 2,5 juta dengan \pm 20 
jenis dari 44 jenis mangrove khas yang ada di dunia. Salah satunya adalah wilayah pesisir Kabupaten Cilacap.

Tanaman bakau hitam (Rhizophora mucronata Lamk.) memiliki kandungan metabolit sekunder yang berpotensi sebagai antioksidan dan antibakteri [2]. Menurut Purwaningsih [3], buah bakau hitam mengandung antioksidan tinggi. Hasil penelitian lanjutan dari Purwaningsih [4], menyatakan bahwa buah bakau hitam memiliki komponen aktif berupa flavonoid, saponin, fenol, hidrokuinon, dan tanin. Antioksidan merupakan suatu senyawa yang dapat menunda atau mencegah reaksi oksidasi dengan cara menghambat terjadinya reaksi rantai oksidatif. Fungsi utama dari antioksidan adalah menetralisasi radikal bebas, sehingga tubuh dapat terlindungi dari berbagai macam penyakit degeneratif [5]. Bentuk sediaan antioksidan yang umum digunakan dalam masyarakat umumnya dalam bentuk sediaan krim, lotion dan gel. Dalam penelitian ini dipilih sediaan nanoemulsi gel (nanoemulgel) sebagai kosmetik untuk antioksidan pada kulit yang diperoleh dari ekstrak buah bakau hitam. Sediaan nanoemulsi dipilih karena memiliki sistem penghantaran obat yang dapat berpenetrasi kedalam lapisan epidermis kulit sehingga dapat meningkatkan bioavaibilitas zat aktifnya [6]. Sediaan gel memiliki keuntungan, yaitu tidak lengket, tidak memerlukan energi yang besar dalam formulasi, stabil, dan mempunyai tampilan yang bagus. Faktor yang paling penting dalam pembuatan sedian gel adalah pemilihan gelling agent [7]. Optimasi menggunakan metode Simplex Lattice Design (SLD) bertujuan untuk menentukan konsentrasi bahan yang tepat sehingga dapat diperoleh formula yang optimum.

Pada penelitian ini dilakukan untuk mengetahui komposisi optimum campuran gelling agent untuk menghasilkan nanoemulgel ekstrak buah bakau hitam yang memenuhi sifat fisik dan stabilitas fisik yang baik.

\subsection{Alat dan Bahan}

\section{METODE PENELITIAN}

Alat yang digunakan dalam penelitian ini antara lain yaitu spektrofotometer UVVis, timbangan digital (Metller Toledo AG 204), alat gelas seperti batang pengaduk, beaker glass, toples kaca untuk maserasi, cawan petri, cawan porselen, kertas saring, aluminium foil, plastik wrap, magnetic stirrer, vortex, sonikator, mortir dan stemper, $\mathrm{pH}$ meter, oven dan Viscometer brookfield.

Bahan yang digunakan untuk pembuatan ekstrak adalah buah bakau hitam $(R$. mucronata Lamk.), metanol, akuades, PEG 400, Tween 80, minyak ikan cucut botol, Hydroxy Propyl Methyl Cellulose (HPMC), viscolam MAC 10, carbopol 940, trietanolamin, propilenglikol, gliserin, metil paraben, propil paraben, dan akuades panas.

\subsection{Jalannya Penelitian}

\subsubsection{Preparasi Sampel}

Buah bakau hitam diambil dari Perhutani Cilacap di Desa Beji Lor, Tritih Kulon, Kecamatan Cilacap Utara, Kabupaten Cilacap sebanyak $2 \mathrm{~kg}$ buah bakau hitam $(R$. mucronata Lamk.). Sampel dipotong tipis-tipis.

\subsubsection{Determinasi Tanaman}

Determinasi buah bakau hitam dilakukan dengan menggunakan referensi berupa jurnal, buku atau referensi lainnya.

\subsubsection{Pembuatan Ekstrak Buah Bakau Hitam}

Buah bakau hitam yang sudah dipotonng sebanyaka $2 \mathrm{~kg}$ dimasukkan ke dalam bejana maserasi, ditambahkan dengan metanol dengan perbandingan $1: 3 \mathrm{~b} / \mathrm{v}$ kemudian ditutup, dibiarkan selama 5 hari 24 jam ditempat terlindung dari cahaya dan sesekali diaduk. Campuran disaring dan ekstrak yang diperoleh diuapkan diatas water bath sampai diperoleh ekstrak kental dan dihitung rendemennya.

\subsubsection{Penetapan Kadar Air}

Sebanyak 5 gram ekstrak diambil, kemudian dikeringkan menggunakan oven selama 3 jam pada suhu $105^{\circ}$ C. Sampel kemudian didinginkan dan ditimbang. Perlakuan diulang 
sampai ditemukan berat konstan dari sampel. Dicatat bobot tetap yang telah diperoleh untuk menghitung persentase susut pengeringan.

\subsubsection{Identifikasi Senyawa Kimia}

a. Alkaloid

Sejumlah ekstrak dilarutkan dalam 3 tetes asam sulfat 2N. Ekstrak diuji menggunakan tiga pereaksi alkaloid yaitu pereaksi Dragendorff, Pereaksi Meyer, Pereaksi Wagner [8].

b. Flavonoid

Ekstrak sebanyak $250 \mathrm{mg}$ ditambahkan 6 tetes HCL pekat dan logam mg. Positif terbentuk warna merah tua menunjukkan adanya senyawa flavonoid [9].

c. Tanin

Ekstrak sebanyak $250 \mathrm{mg}$ ditambahkan air hangat $3 \mathrm{~mL}$. Ditambahkan $\mathrm{FeCl} 1 \% 2$ tetes. Positif terbentuk warna hijau kehitaman [10].

d. Steroid/Triterpenoid

Sejumlah sampel dilarutkan dalam $2 \mathrm{~mL}$ kloroform, ditambahkan 10 tetes anhidrat asetat dan 3 tetes asam sulfat pekat. Reaksi positif terbentuknya larutan berwarna merah untuk pertama kali kemudian berubah menjadi biru dan hijau [8].

e. Fenol hidrokuinon

Sampel sebanyak 1 gram diekstrak dengan $20 \mathrm{~mL}$ etanol 90\%, diambil 1 $\mathrm{mL}$ ditambah 2 tetes larutan $\mathrm{FeCl}_{3} 5 \%$. Positif adanya senyawa fenol apabila terbentuknya warna hijau atau hijau biru [8].

\subsubsection{Pembuatan Nanoemulsi}

Tabel I. Formulasi Acuan Nanoemulsi Yang Digunakan [11]

\begin{tabular}{|c|c|c|c|}
\hline No & Bahan & Formula acuan & $\begin{array}{c}\text { Formula } \\
\text { modifikasi }\end{array}$ \\
\hline 1 & Ekstrak Temulawak & $50 \mathrm{mg}$ & - \\
\hline 2 & Ekstrak buah bakau hitam & - & $0,5 \%$ \\
\hline 3 & Tween 80 & $6 \mathrm{~mL}$ & $6 \mathrm{~mL}$ \\
\hline 4 & PEG 400 & $1 \mathrm{~mL}$ & $1 \mathrm{~mL}$ \\
\hline 5 & Minyak Ikan Cucut Botol & $1 \mathrm{~mL}$ & $1 \mathrm{~mL}$ \\
\hline 6 & Aquadest & q.s & q.s \\
\hline
\end{tabular}

\subsubsection{Pembuatan Sediaan Nanoemulgel}

Tabel II. Komposisi Bahan untuk Menentukan Formulasi Optimum

\begin{tabular}{|c|c|c|c|c|c|c|c|c|c|}
\hline $\begin{array}{c}\text { Formul } \\
\mathbf{a}\end{array}$ & $\begin{array}{c}\text { Nanoemul } \\
\mathbf{s i} \text { Ekstrak } \\
\text { (gram) }\end{array}$ & $\begin{array}{c}\text { HPM } \\
\mathbf{C} \\
\text { (gram) }\end{array}$ & $\begin{array}{c}\text { Carbop } \\
\text { ol 940 } \\
\text { (gram) }\end{array}$ & $\begin{array}{c}\text { Viscola } \\
\text { m MAC } \\
\mathbf{1 0} \\
(\text { gram) }\end{array}$ & $\begin{array}{c}\text { Gliseri } \\
\mathbf{n} \\
\text { (gram) }\end{array}$ & $\begin{array}{c}\text { Propilengl } \\
\text { ikol } \\
\text { (gram) }\end{array}$ & $\begin{array}{c}\text { Metil } \\
\text { Parabe } \\
\text { n } \\
\text { (gram) }\end{array}$ & $\begin{array}{c}\text { Propil } \\
\text { Parab } \\
\text { en } \\
\text { (gram) }\end{array}$ & $\begin{array}{c}\text { Akuade } \\
\text { s ad } \\
\text { (gram) }\end{array}$ \\
\hline 1 & 0,5 & 2,3 & 1,5 & 5,5 & 2,5 & 7,5 & 0,1 & 0,025 & 100 \\
\hline 2 & 0,5 & 4 & 0,5 & 5 & 2,5 & 7,5 & 0,1 & 0,025 & 100 \\
\hline 3 & 0,5 & 2 & 2 & 5 & 2,5 & 7,5 & 0,1 & 0,025 & 100 \\
\hline 4 & 0,5 & 4 & 0,5 & 5 & 2,5 & 7,5 & 0,1 & 0,025 & 100 \\
\hline 5 & 0,5 & 3 & 0,5 & 5 & 2,5 & 7,5 & 0,1 & 0,025 & 100 \\
\hline 6 & 0,5 & 2 & 0,5 & 8 & 2,5 & 7,5 & 0,1 & 0,025 & 100 \\
\hline 7 & 0,5 & 3 & 1,25 & 5 & 2,5 & 7,5 & 0,1 & 0,025 & 100 \\
\hline 8 & 0,5 & 2 & 1,25 & 6,5 & 2,5 & 7,5 & 0,1 & 0,025 & 100 \\
\hline 9 & 0,5 & 2,6 & 0,9 & 5,9 & 2,5 & 7,5 & 0,1 & 0,025 & 100 \\
\hline 10 & 0,5 & 3 & 0,5 & 6,5 & 2,5 & 7,5 & 0,1 & 0,025 & 100 \\
\hline 11 & 0,5 & 2 & 0,5 & 8 & 2,5 & 7,5 & 0,1 & 0,025 & 100 \\
\hline 12 & 0,5 & 3,3 & 0,75 & 5,5 & 2,5 & 7,5 & 0,1 & 0,025 & 100 \\
\hline 13 & 0,5 & 2,3 & 0,75 & 7,0 & 2,5 & 7,5 & 0,1 & 0,025 & 100 \\
\hline 14 & 0,5 & 2 & 2 & 5 & 2,5 & 7,5 & 0,1 & 0,025 & 100 \\
\hline
\end{tabular}


Tabel III. Formulasi Acuan Nanoemulgel [7]

\begin{tabular}{|c|c|c|}
\hline No & Bahan & Formulasi acuan (\%) \\
\hline 1 & Ekstrak fase minyak nanoemulsi & 1 \\
\hline 2 & Ekstrak fase minyak nanoemulsi buah bakau & - \\
\hline 3 & HPMC & 5 \\
\hline 4 & Carbopol 940 & 1 \\
\hline 5 & Viiscolam MAC 10 & 20 \\
\hline 6 & Giserin & 5 \\
\hline 7 & Propilenglikol & 0,2 \\
\hline 8 & Metal paraben & 0,05 \\
\hline 9 & Propil paraben & 100 \\
\hline 10 & Akuades ad & \\
\hline
\end{tabular}

\subsubsection{Uji Evaluasi}

Uji evaluasi meliputi uji sifat fisik [12], dan stabilitas fisik [13]meliputi:

a. Uji Organoleptis

Uji organoleptis diamati secara langsung dari bentuk, warna, dan bau dari sediaan yang dibuat.

b. Uji pH

Uji $\mathrm{pH}$ dengan cara $\mathrm{pH}$ meter dicelupkan pada sediaan kemudian dilihat pada parameter $\mathrm{pH}$.

c. Uji Homogenitas

Uji homogenitas di ambil secukupnya dioleskan pada kaca objeck. Dilihat sediaan ada butiran kasar atau tidak.

d. Uji Daya Sebar

Uji daya sebar sediaan ditimbang $500 \mathrm{mg}$, diletakkan dialat ekstensometer dan ditutup, dibiarkan selama 1 menit. Diukur diameter yang menyebar dengan mengamati rata-rata diameter dari beberapa sisi. Ditambahakn beban 50 gram, diamkan selama 1 menit dan catat diameter seperti sebelumnya. Diteruskan dengan menambahkan beban lagi seberat 50 gram dan cacat diameter sediaan setelah 1 menit dan catat diameter sediaan seperti sebelumnya.

e. Uji Viskositas

Uji viskositas sebanyak 60 gram sediaan ditempatkan pada alat viscometer brokfield, diatur spindel nomor 4 dengan kecepatan $30 \mathrm{rpm}$. Setelah menunjukan data yang stabil, dicatat hasilnya.

\subsection{Analisis Data}

Teknik analisis data pada Optimasi Formula Nanoemulsi Gel Ekstrak Buah Bakau Hitam (Rhizophora mucronata Lamk.) dengan Variasi Gelling Agent HPMC, carbopol 940 dan viscolam MAC 10 yaitu dengan menggunakan uji t dan analisis deskriptif.

\subsection{Preparasi Sampel}

\section{HASIL DAN PEMBAHASAN}

Diperoleh simplisia basah sebanyak $2 \mathrm{~kg}$, dengan warna simplisia coklat kehitaman.

\subsection{Determinasi Tanaman}

Determinasi tanaman dilakukan untuk mengetahui kebenaran dari tanaman tersebut, sehingga tidak terjadi kesalahan dalam pengambilan dan pengumpulan bahan. Hasil determinasi menggunakan hasil literatur atau referensi berupa buku dari panduan mangrove perancak dan panduan pengenalan mangrove di Indonesia diperoleh hasil bahwa tanaman yang digunakan dalam pembuatan sediaan nanoemulsi gel ekstrak buah bakau hitam (Rhizophora mucronata Lamk.) merupakan tanaman 
Rhizophora mucronata atau biasa disebut bakau hitam yang merupakan family dari Rhizophoraceae yang merupakan tanaman mangrove.

\subsection{Pembuatan Ekstrak Buah Bakau Hitam}

Hasil ekstrak yang didapat dari pembuatan ekstrak sebesar 180,58 gram dengan ekstrak kental berwarna coklat kehitaman dengan nilai rendemen yang didapat sebesar $9,0 \%$.

\subsection{Penetapan Kadar Air}

Penetapan kadar air merupakan standar yang digunakan untuk menghindari pertumbuhan suatu mikroorganisme pada ekstrak [14]. Hasil penetapan kadar air pada ekstrak buah bakau hitam sebesar $0,87 \%<10 \%$. Sehingga dapat disimpulkan bahwa ekstrak yang didapat memenuhi standar yang berlaku, sehingga ekstrak dapat terhindar dari pertumbuhan mikroorganisme

\subsection{Identifiasi Senyawa Kimia}

Identifikasi senyawa kimia bertujuan untuk mengetahui senyawa yang terdapat didalam ekstrak yang digunakan. Hasil identifikasi senyawa kimia ekstrak buah bakau hitam dapat dilihat pada tabel IV.

Tabel IV. Hasil Identifikasi Senyawa Kimia Ekstrak Buah Bakau Hitam

\begin{tabular}{|c|c|c|}
\hline Metabolit sekunder & Hasil & Keterangan \\
\hline $\begin{array}{l}\text { Alkaloid } \\
\text { Pereaksi Dragendorff } \\
\text { Pereaksi Meyer } \\
\text { Pereaksi Wagner }\end{array}$ & $\begin{array}{l}(+) \\
(-) \\
(+)\end{array}$ & $\begin{array}{l}\text { Endapan merah jingga } \\
\text { Tidak terdapat endapan putih kekuningan } \\
\text { Endapan coklat }\end{array}$ \\
\hline Flavonoid & $(+)$ & Warna Merah tua \\
\hline Tanin & $(+)$ & Warna Hijau kehitaman \\
\hline Steroid/Triterpenoid & $(+)$ & Warna Merah \\
\hline Fenol hidrokuinon & $(+)$ & Warna Hijau \\
\hline
\end{tabular}

Keterangan: $(+)=$ Positif, $(-)=$ Negatif

\subsection{Pembuatan Nanoemulsi}

Hasil pembuatan nanoemulsi dilihat nilai transmitannya, hasil yang didapat menunjukkan hasil bahwa sediaan nanoemulsi yang dibuat dengan penambahan akuades dengan konsentrasi yang berbeda dari $5 \mathrm{ml}, 7,5 \mathrm{ml}$ dan $10 \mathrm{ml}$ menghasilan nilai transmitan yang mendekati $100 \%$ yaitu $96,9 \%, 98,1 \%$, dan $98,3 \%$. Sediaan nanoemulsi yang dibuat dengan penambahan akuades sebanyak $10 \mathrm{ml}$ memiliki kejernihan yang mendekati standar kejernihan yang dapat disimpulkan bahwa sediaan mendekati ukuran nanometer. Kemudian sampel yang telah diketahui nilai transmitannya diuji menggunakan uji Particle Size Analyzer (PSA) diperoleh hasil bahwa sediaan nanoemulsi ekstrak buah bakau hitam memiliki ukuran tetesann nanoemulsi rata-rata sebesar $24,3 \mathrm{~nm}$ dan nilai distribusi ukuran atau polydispersity index rata-rata sebesar 0,555 , hal ini menunjukan bahwa sediaan telah mencapai standar sebagai sediaan nanoemulsi dengan ukuran partikel yang masuk dalam rentan sediaan nanoemulsi yaitu 10 hingga $1000 \mathrm{~nm}$, sehingga sediaan sesuai dengan hasil transmitan sebelumnya yang memberikan gambaran awal sebagai sediaan nanoemulsi dan distribusi ukuran yang kurang dari 1 yang menunjukan bahwa sediaan memiliki distribusi ukuran yang homogen. Dan pada pengukuran Potensial Zeta dilakukan untuk mengetahui parameter muatan listrik antara partikel koloid. Nilai potensial zeta berperan dalam menentukan kestabilan dari sediaan nanoemulsi. Berdasarkan hasil uji yang telah dilakukan menggunakan alat Zetasizer menunjukan bahwa nilai potensial zeta rata-rata sebesar $13,4 \mathrm{mV}$, suatu formulasi nanoemulsi dikatakan stabil apabila nilai potensial zeta lebih dari $30 \mathrm{mV}$ [15]. Sehingga dapat disimpulkan bahwa sediaan 
nanoemulsi yang dibuat memiliki stabilitas yang rendah. Hasil data pengukuran ukuran partikel dan distribusi ukuran atau polydispersity index dapat dilihat pada tabel dibawah ini:

Tabel V. Hasil Data Distribusi Ukuran Partikel

\begin{tabular}{|c|c|c|}
\hline No & Distribusi Ukuran & polydispersity index (PI) \\
\hline 1 & $23,3 \mathrm{~nm}$ & 0,567 \\
\hline 2 & $24,8 \mathrm{~nm}$ & 0,581 \\
\hline 3 & $24,8 \mathrm{~nm}$ & 0,518 \\
\hline $\mathrm{X}$ & $24,3 \mathrm{~nm}$ & 0,555 \\
\hline
\end{tabular}

Tabel VI. Hasil Data Potensial Zeta

\begin{tabular}{|c|c|c|}
\hline No & Zeta Potensial (Mean) & Electrophoretic Mobility Mean \\
\hline 1 & $13,1 \mathrm{mV}$ & $0,000101 \mathrm{~cm}^{2} / \mathrm{Vs}$ \\
\hline 2 & $13,9 \mathrm{mV}$ & $0,000107 \mathrm{~cm}^{2} / \mathrm{Vs}$ \\
\hline 3 & $13,3 \mathrm{mV}$ & $0,000103 \mathrm{~cm}^{2} / \mathrm{Vs}$ \\
\hline $\mathrm{x}$ & $13,4 \mathrm{mV}$ & \\
\hline
\end{tabular}

\subsection{Pembuataan Sediaan Nanoemulgel}

Pembuatan sediaan nanoemulgel menggunakan variasi gelling agent yaitu HPMC, Carbopol 940 dan Viscolam MAC 10. Basis HPMC, basis viscolam MAC 10, basis Carbopol 940 ditaburkan diatas air, dibiarkan sampai mengembang, diaduk sampai terbentuk masa gel, ditambahkan trietanolamin sampai terbentuk masa gel yang jernih. Nanoemulsi buah bakau ditambahkan ke dalam basis kemudian ditambahkan eksipien lain seperti propilenglikol, gliserin, metil paraben dan propil paraben dalam keadaan terlarut, setelah itu diaduk hingga terbentuk gel dengan konsistensi yang baik dan dilakukan uji evaluasi sediaan.

\subsection{Uji Evaluasi}

\subsubsection{Uji Organoleptis}

Uji organoleptis dari keempat belas formula sebelum dan sesudah dilakukan uji stabilitas fisik menghasilkan sediaan dengan bentuk gel, warna merah muda pada formula (I, II, III, VI, VII, VIII, IX, X, XII, XIII, XIV) dan ungu muda pada formula $(\mathrm{IV}, \mathrm{V}, \mathrm{XI})$, serta bau yang relatif sama.

\subsubsection{Uji pH}

Uji pH dari keempat belas formula sebelum dan sesudah dilakukan uji stabilitas fisik memiliki $\mathrm{pH}$ yang sesuai dengan $\mathrm{pH}$ kulit yaitu 5,5-7, dengan kriteria $\mathrm{pH}$ pada sediaan gel yang memenuhi persyaratan SNI No.16-4399-1996 yaitu antara 4,5-8,0.

\subsubsection{Uji Homogenitas}

Uji homogenitas dari keempat belas formula sebelum dan sesudah dilakukan uji stabilitas fisik menghasilkan sediaan yang homogen, sehingga sediaan memenuhi standar persyaratan SNI No. 06-2588-1992 yaitu sediaan gel tidak memiliki butiran kasar atau gumpalan-gumpalan dalam sediaan yang dibuat.

\subsubsection{Uji Daya Sebar}

Uji daya sebar dari keempat belas formula sebelum dan sesudah dilakukan uji stabilitas fisik menunjukkan bahwa daya sebar tidak memenuhi standar daya sebar yang baik, dimana daya sebar kurang darai standar SNI yaitu antara 5,54-6,08 cm karena rata-rata daya sebar yang diperoleh berkisar dari 1,62 sampai $2,43 \mathrm{~cm}$.

\subsubsection{Uji Viskositas}

Uji viskositas dari keempat belas formula sebelum dilakukan uji stabilitas fisik menunjukan hasil memenuhi standar menurut SNI 16-4380-1996 dengan nilai viskositas sebesar 49089 Cps. Sedangkan setelah dilakukan uji stabilits fisik sediaan mengalami perubahan sebesar 1375 Cps.

\subsubsection{Penentuan Optimasi Formula Nanoemulgel Ekstrak Buah Bakau Hitam}

a. Daya sebar

Berdasarkan hasil yang diperoleh dari software design expert versi 10.0.1 menunjukkan hasil bahwa masing-masing komponen memberikan pengaruh 
terhadap daya sebar nanoemulgel, dimana HPMC dan viscolam MAC 10 merupakan faktor yang paling berpengaruh terhadap daya sebar dengan nilai koefisien HPMC +0,16 diikuti viscolam MAC $10+0,16$ dan carbopol $940+0,66$. Contour plot untuk daya sebar dapat dilihat pada gambar 1.

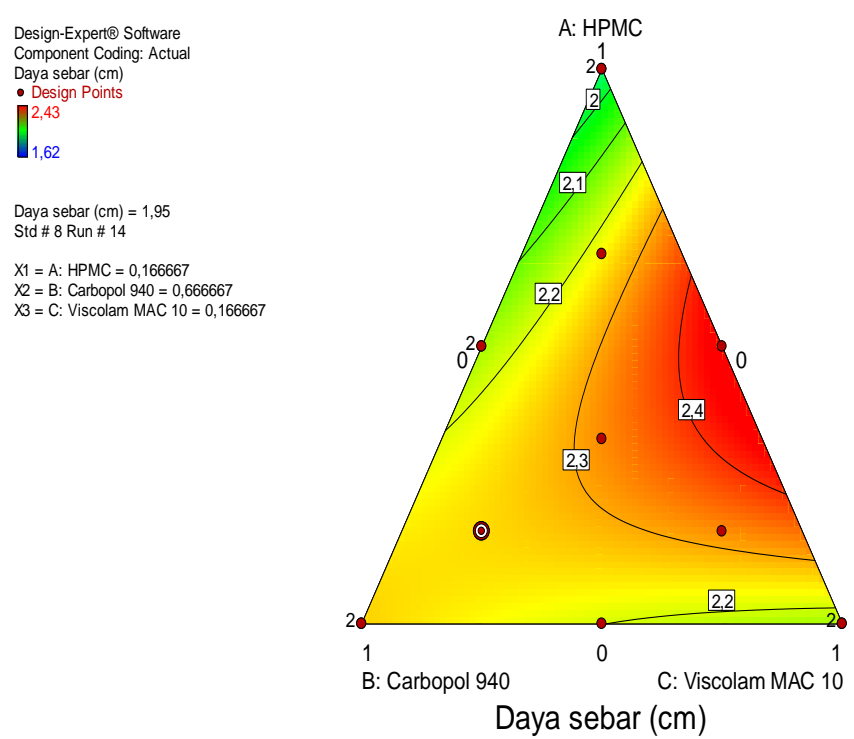

Gambar 1. Diagram Contour plot Daya Sebar Nanoemulgel Ekstrak Buah Bakau Hitam

Terlihat data daya sebar tersebar secara tidak merata mengikuti garis linier dan tidak hanya mengelompok.

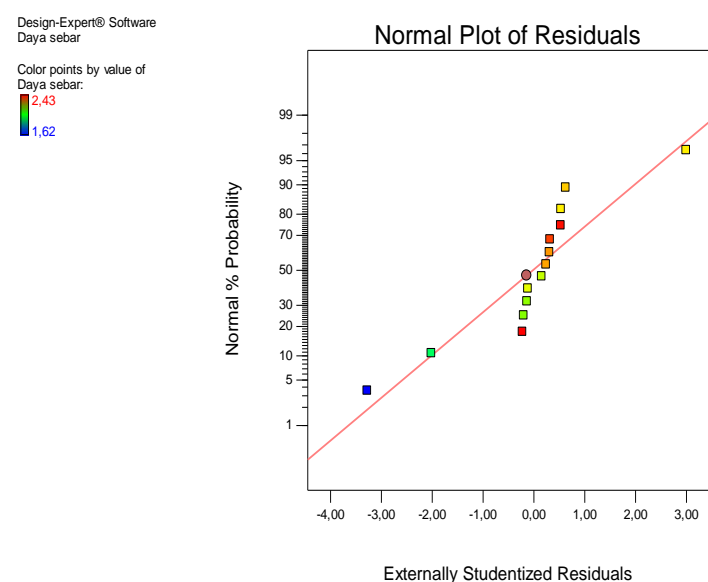

Gambar 2. Normal Plot Of Residuals Data Daya Sebar Nanoemulgel Ekstrak Buah Bakau Hitam

b. Viskositas

Berdasarkan hasil yang diperoleh dari software design expert versi 10.0.1 masing-masing komponen memberikan pengaruh terhadap viskositas sediaan nanoemulgel. Masing-masing komponen baik HPMC, carbopol 940 dan viscolam MAC 10 memberikan pengaruh positif menaikan viskositas dari sediaan nanoemulgel, dimana HPMC dan viscolam MAC 10 merupakan faktor yang paling 
berpengaruh dengan nilai koefisien HPMC $+0,16$ diikuti viscolam MAC $10+0,16$ dan carbopol $940+0,66$. Data dapat dilihat pada gambar 3 .

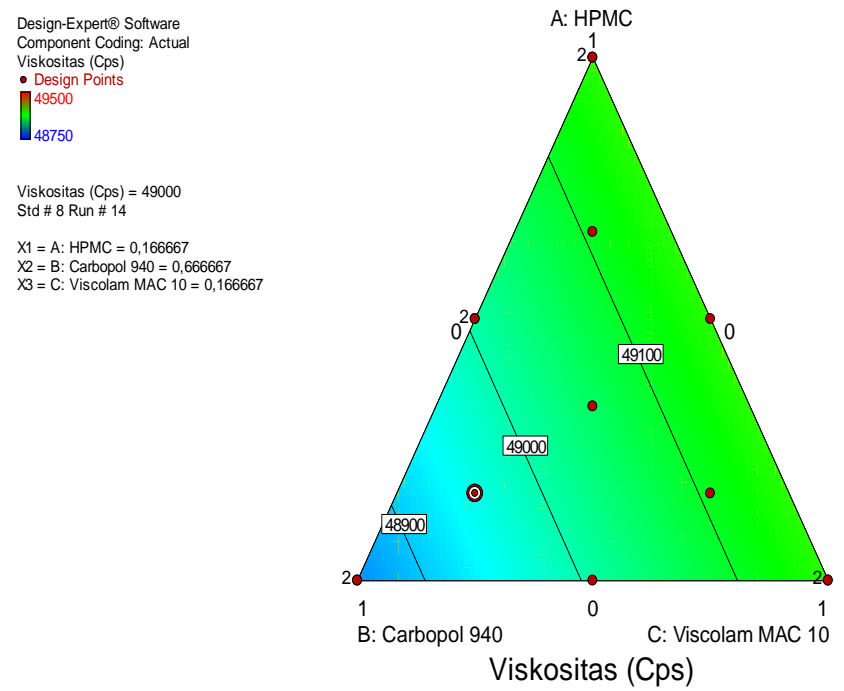

Gambar 3. Diagram Contour Plot Viskositas Nanoemulgel Ekstrak Buah Bakau Hitam

Terlihat data viskositas tersebar secara merata mengikuti garis linier dan tidak hanya mengelompok. Data dapat dilihat pada gambar 4.

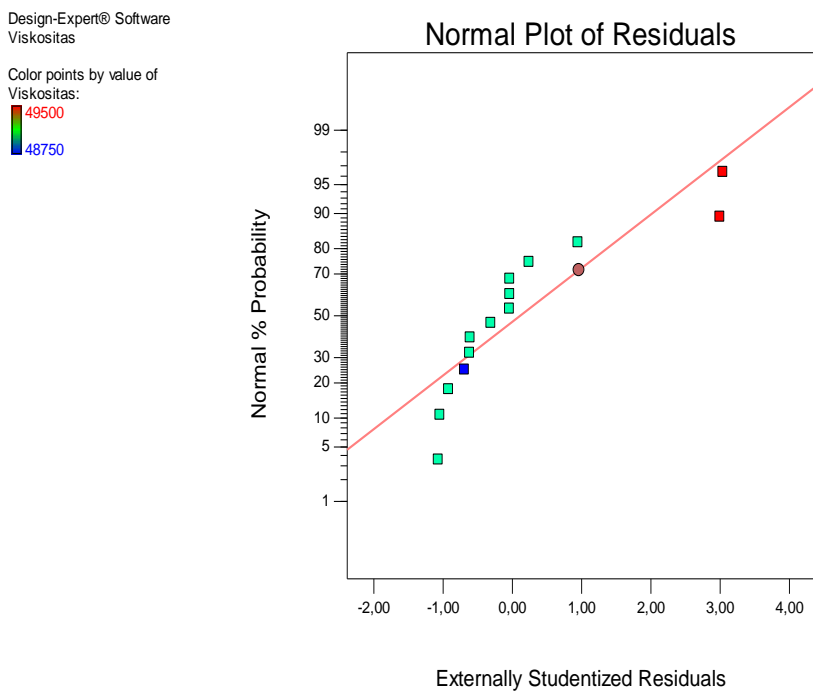

Gambar 4. Normal Plot Of Residuals Data Viskositas Nanoemulgel Ekstrak Buah Bakau Hitam

c. Perubahan Viskositas

Berdasarkan hasil pengukuran menggunakan software design expert versi 10.0.1 menunjukkan hasil HPMC, carbopol 940 dan viscolam MAC 10 memberikan pengaruh terhadap perubahan viskositas sediaan nanoemulgel. Masing-masing komponen memiliki nilai koefisien HPMC +1 diikuti viscolam MAC $10+0$ dan diikuti carbopol $940+0$. HPMC dann viscolam MAC 10 memberikan pengaruh positif peningkatan perubahan viskositas. Data dapat dilihat pada gambar 5 . 


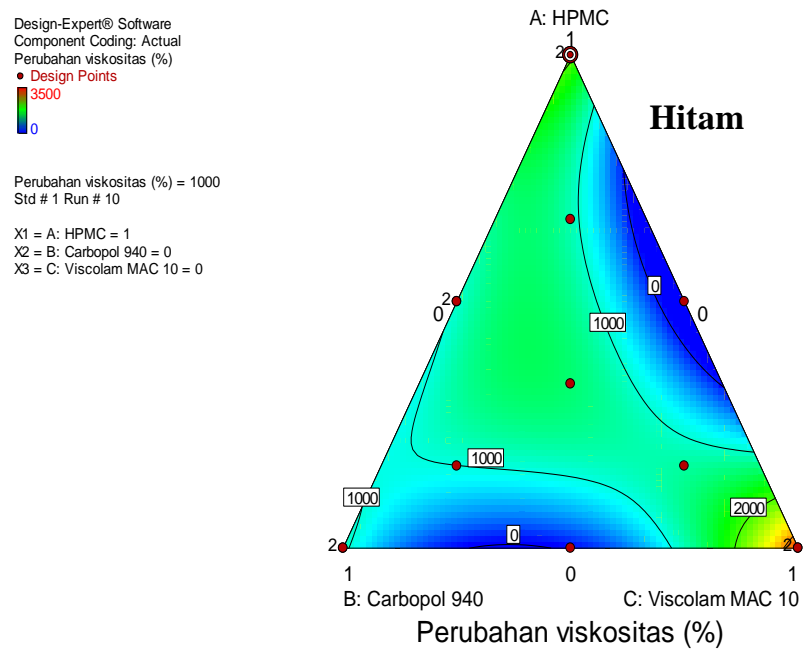

Gambar 5. Diagram Contour Plot Perubahan Viskositas Nanoemulgel Ekstrak Buah Bakau

Terlihat data perubahan viskositas tersebar secara merata mengikuti garis linier dan tidak hanya mengelompok.

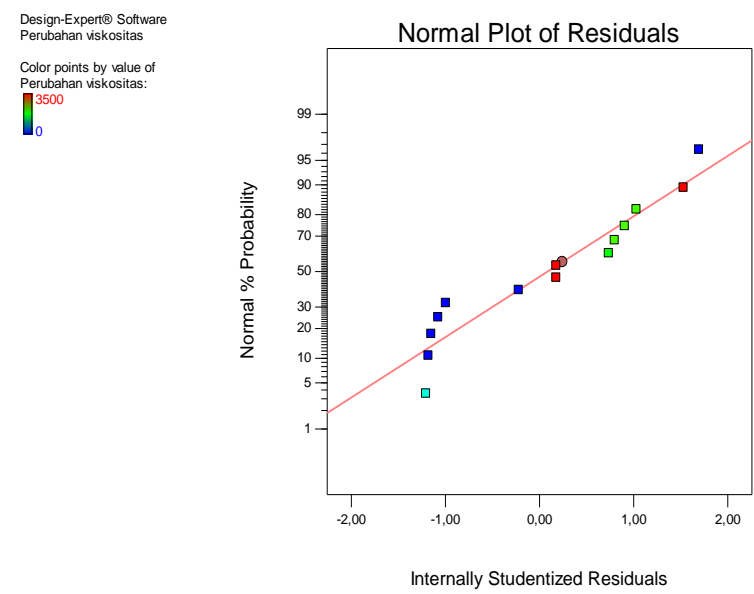

Gambar 6. Normal Plot Of Residuals Data Perubahan Viskositas Nanoemulgel Ekstrak Buah Bakau Hitam

\subsubsection{Penentuan Formula Optimum Nanoemulgel Ekstrak Buah Bakau Hitam}

Penentuan daerah optimum sediaan nanoemulgel ekstrak buah bakau hitam menggunakan software Design Expert 10.0.1. pada penelitian ini digunakan pendekatan numerik untuk menentukan formulasi optimum. Data yang dimasukkan sebagai respon adalah sifat fisik dan stabilitas fisik sediaan yaitu daya sebar 5,546,08 cm, viskositas 2000-50000 Cps, dan perubahan viskositas 2000-50000 Cps. Berdasarkan ketiga respon tersebut dibuatlah diagram super imposed contour plot untuk menentukan daerah optimum. Data dapat dilihat pada gambar 7. 


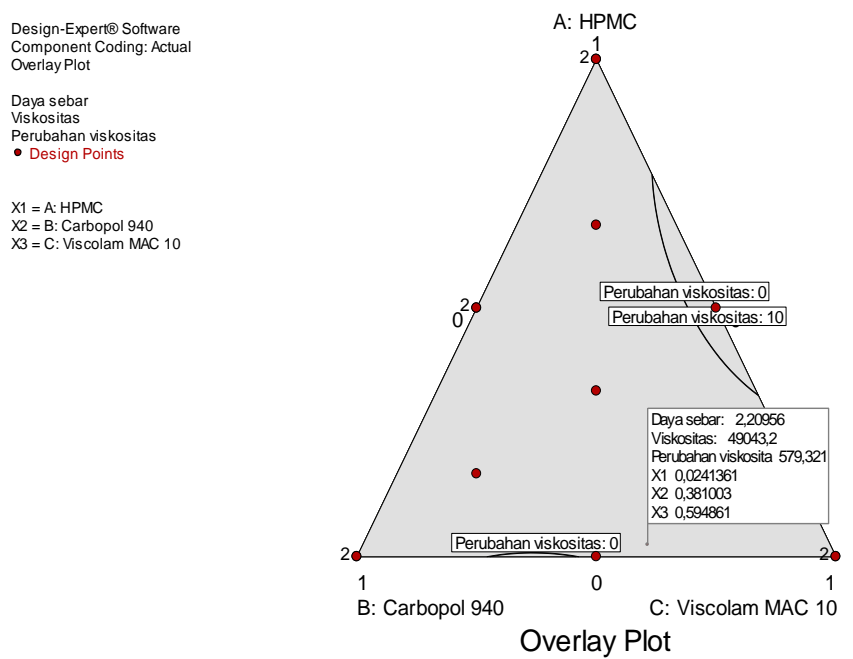

Gambar 7. Diagram Super Imposed Contour Plot Formula Optimum Nanoemulgel Ekstrak Buah Bakau Hitam

Pada diagram super imposed contour plot (gambar ) menunjukan bahwa formula yang dipilih sebagai formula optimum menggunakan software Design Expert 10.0.1 adalah formula yang mengandung HPMC 0,024\%, carbopol 940 0,38\% dan viscolam MAC 10 0,59\%. Selain itu software juga menunjukan hasil nilai prediksi dari sifat fisik dan stabilitas fisik dari formula optimum, yaitu dengan daya sebar 2,21 cm, viskositas 49043,2 Cps dan perubahan viskositas 579,3 Cps.

Formula optimum berdasarkan software Design Expert versi 10.0.1 sebagai berikut:

$\begin{array}{lc}\text { Ekstak nanoemulsi buah bakau hitam } & 1 \% \\ \text { HPMC } & \mathbf{0 , 0 2 4 \%} \\ \text { Carbopol 940 } & \mathbf{0 , 3 8 \%} \\ \text { Viscolam MAC 10 } & \mathbf{0 , 5 9 \%} \\ \text { Gliserin } & 5 \% \\ \text { Propilenglikol } & 15 \% \\ \text { Metil Paraben } & 0,2 \% \\ \text { Propil Paraben } & 0,05 \% \\ \text { Aquadest } & 100 \%\end{array}$

\subsubsection{Verifikasi Formula Optimum}

Pengujian verifikasi formula optimum dianalisis menggunakan software Design Expert versi 10.0.1. selanjutnya dibandingkan dengan respon yang diperoleh pada percobaan. Uji yang digunakan yaitu uji-t satu sampel yang digunakan untuk menguji perbedaan rata-rata suatu sampel dengan nilai hipotesis. Hasil uji-t satu sampel respon prediksi dan respon percobaan formula optimum dapat dilihat pada tabel VII.

Tabel VII. Hasil Uji-t Satu Sampel Formula Prediksi Dibandingkan Fomula Optimum Percobaan

\begin{tabular}{|l|c|c|c|l|}
\hline \multicolumn{1}{|c|}{ Respon } & Prediksi & Percobaan & $\begin{array}{c}\text { Signifikansi } \\
\text { 2-tailed }\end{array}$ & Kesimpulan \\
\hline Daya sebar (cm) & 2,21 & 2,20 & 0,01 & $\begin{array}{l}\text { Berbeda } \\
\text { signifikan }\end{array}$ \\
\hline Viskositas (Cps) & 49043,2 & 49089,0 & 0,00 & $\begin{array}{l}\text { Berbeda } \\
\text { signifikan }\end{array}$ \\
\hline Perubahan viskositas (Cps) & 579,3 & 1089,0 & 0,189 & $\begin{array}{l}\text { Tidak berbeda } \\
\text { signifikan }\end{array}$ \\
\hline
\end{tabular}


Berdasarkan tabel VII dilakukan analisis statistik menggunakan uji analisis single sample t-Test untuk membandingkan hasil percobaan dengan nilai prediksi software design expert versi 10.0.1. Hasil analisis statistik yang diperoleh menunjukkan bahwa antara nilai prediksi dan nilai percobaan yang diperoleh ada perbedaan signifikan pada evaluasi daya sebar dan viskositas. Hal ini ditunjukkan oleh nilai P (signifikansi 2-tailed) yang kurang dari 0,05 , tetapi nilai prediksi dan nilai percobaan tidak ada perbedaan signifikan hanya pada evaluasi perubahan viskositasnya. Hal ini ditunjukkan oleh nilai $\mathrm{P}$ (signifikansi 2-tailed) yang lebih besar dari 0,05 .

\section{KESIMPULAN}

Formulasi optimum campuran gelling agent untuk menghasilkan nanoemulgel ekstrak buah bakau hitam yang memenuhi sifat fisik dan stabilitas fisik yang baik adalah nanoemulgel pada formula VI, dan pada hasil penentuan formula optimum nanoemulgel ekstrak buah bakau hitam diperoleh dengan campuran HPMC 0,024\%, carbopol 940 $0,38 \%$ dan viscolam MAC 10 0,59\%. Dengan nilai respon yang diperoleh untuk evaluasi dengan daya sebar 2,21 cm, viskositas 49043,2 Cps dan perubahan viskositas 579,3 Cps. HPMC dan viscolam MAC 10 merupakan faktor dominan yang dapat meningkatkan daya sebar, viskositas serta perubahan viskositas dari sediaan nanoemulgel.

\section{DAFTAR PUSTAKA}

[1] Farhaeni, M, (2016) 'Jurnal Studi Kultural Komodifikasi Ragam Buah Mangrove untuk Pemberdayaan Masyarakat Pesisir di Desa' Jurnal Studi Kultural, I(1), hal. 21-27.

[2] Kurnianingsih, Dewi., Setiabudi, Lulu., Tajudin, Tatang, Uji Efektivitas Sediaan Krim Kombinasi Ekstrak Daun Bakau Hitam (Rhizophora Mucronata) Dan Jeruk Purut (Citrus Hystrix) Terhadap Bakteri Staphylococcus Aureus, Jurnal Ilmiah Jophus : Journal of Pharmacy UMUS, Vol. 2 No. 01, Agustus 2020.

[3] Purwaningsih, S., Salamah, E., Sukarno, A.Y.P., Deskawati, E. (2013) 'Aktivitas Antioksidan Dari buah Mangrove (Rhizophora mucronata Lamk.) Pada Suhu Yang Berbeda' JPHPI, Vol.16 No.3199-206. Institut Pertanian Bogor. Bogor

[4] Purwaningsih, S. et al. (2014) 'Formulasi Skin Lotion dengan Penambahan Karagenan dan Antioksidan Alami dari Rhizophora mucronata Lamk' Jurnal Akuatika, Vol.V , No.1.55-62. Fakultas Perikanan dan Ilmu Kelautan. Institut Pertanian Bogor. Bogor.

[5] Priyanto, R. A. (2012) 'Aktivitas Antioksidan dan Komponen Bioaktif Pada Buah Bakau ( Rhizophora mucronata Lamk .)' Skripsi.

[6] Budiarto, Widi., Rochmah, Nikmah Nuur., Setiyabudi, Lulu, Formulasi Sediaan Nanoemulsi Ekstrak Daun Mangrove Avicennia Marina Dengan Virgin Coconut Oil Sebagai Fase Minyak, Jurnal Ilmiah Jophus : Journal of Pharmacy UMUS, Vol. 2 No. 01, Agustus 2020.

[7] Hajrah, Lisna Meylina, Riski Sulistiarini, Lia Puspitasari, A. P. K, (2017) 'Optimasi Formula Nanoemulgel Ekstrak Daun Pidada Merah (Sonneratia Caseolaris L ) dengan Variasi Gelling Agent' Jurnal Sains dan Kesehatan, 1(7), hal. 333-337.

[8] Harborne JB. (1984) 'Metode Fitokimia' Padwaminata K, Soediro I, Bandung: ITB Press, Terjemahan dari: Phytochemical method $2^{\text {nd }}$. Hm 69-274.

[9] Wulandari, S. A. R. (2017) 'Formulasi Uji Aktivitas Antibakteri Staphylococcus epidermis Sediaan Mikroemulsi Ekstrak Daun Kersen (Muntingi acaluburalin) dengan Fase Minyak Isopropyl Mirystate' Skripsi.

[10] Lestari, J. H. (2016) 'Dekok Daun Kersen (Muntingia calabura) Sebagai Cairan Sanitasi Tangan Dan Buah Apel Manalagi’ Skripsi. 
[11] Priambudi, Dani R. (2019) 'Optimasi Formulasi Self Nanoemulsifying Drug Delivery System (SNEDDS) Ekstrak Etanol Daun Sukun (Artocarpus altilis) dengan Metode Simplex Lattice Design' Skripsi.

[12] Azimah, N. (2019) 'Formulasi dan Evaluasi Masker Gel Peel Off Kombinasi Ekstrak Rumput Laut (Eucheuma cottonii) dengan Vitamin C Sebagai Antioksidan' Skripsi.

[13] Iradhati A.H., and Jufri M. (2017) 'Formulation and Physical Stability Test of Griseofulvin Microemulsion Gel' International Journal of Applied Pharmaceutics, 9(April), 7-10.

[14] Soetarno, S., \& I. S., Soediro. (1997) 'Standardisasi Mutu Simplisia dan Ekstrak Bahan Obat Tradisional' Presidium Temu Ilmiah Nasional Bidang Farmasi.

[15] Handayani, F.S., Nugroho, B.H., Munawiroh, S.Z. (2018) 'Optimasi Formulasi Nanoemulsi Minyak Biji anggur Energi Rendah dengan D-Optimal Mixture Design (DMD)' Jurnal Ilmiah Farmasi, 17-34, Universitas Islam Indonesia. Yogyakarta. 